\title{
Ethnobotany of Breadfruit in Vanuatu: Review and Prospects
}

Jean-Pierre Labouisse ${ }^{1 *}$

${ }^{1}$ CIRAD Centre de Coopération Internationale en Recherche Agronomique pour le Développement, UMR AGAP, F-34398 Montpellier, France.

*jean-pierre.labouisse@cirad.fr

\begin{abstract}
Breadfruit is a traditional staple crop and an important component of Pacific Island agrosystems. This article reviews documentation related to breadfruit in Vanuatu with a focus on ethnobotanical data recorded from the first contacts with European voyagers and missionaries to the most recent survey conducted on several islands in 2009. Tree management practices, food and non-food uses, conservation techniques, as well as ritual magic intended to increase yields and protect the crop, are described. A database of 539 cultivar names has been compiled. Some lines for future research within the social and biological sciences are proposed.
\end{abstract}

Received December 8, 2016

OPEN ӘACCESS

Accepted January 21, 2016

DOI 10.14237/ebl.7.1.2016.582

Keywords Artocarpus, Food conservation, Pacific, Ritual magic, Staple crop, Tree farming

Copyright (C) 2016 Labouisse; licensee Society of Ethnobiology. This is an open-access article distributed under the terms of the Creative Commons AttributionNonCommercial 4.0 International Public License (https://creativecommons.org/licenses/by-nc/4.0), which permits non-commercial use, distribution, and reproduction in any medium, provided the original author and source are credited.

Supplementary File available at ojs.ethnobiology.org/index.php/ebl.

\section{Introduction}

Breadfruit (Artocarpus altilis) is a traditional staple crop and an important component of Pacific Island agrosystems (Barrau 1958; Ragone 1997; Yen 1974). In the past it was a key element for islanders' food security thanks to the potential of the tree to produce high yields under low-input conditions. A range of food and non-food uses, processing and conservation methods, rituals for celebrating harvests, as well as legends associated with breadfruit attest to its cultural importance in the Pacific. While the ethnobotanical literature is particularly rich for Polynesia and Micronesia (e.g., Lepofsky 2003; Pollock 1992; Ragone 1991), information on breadfruit in Vanuatu is dispersed over a number of articles, books and gray literature. To date, only one article by Walter (1989) gives a general overview of the crop, with observations collected on eight islands, but no recent and comprehensive review of the literature has been conducted. This article organizes published and unpublished material related to breadfruit in Vanuatu, with a focus on ethnobotanical data recorded from the first contacts with European voyagers and missionaries to the most recent survey conducted in 2009. Some lines for future research on breadfruit within the social and biological sciences are proposed in concluding remarks.

\section{Breadfruit Origins and Dispersal}

Recent genetic studies of the genus Artocarpus have shed new light on the origins and evolution of breadfruit and related species in the Pacific. Using genetic markers, Zerega et al. (2004) demonstrated that $A$. altilis derived from $A$. camansi, a species with large and numerous seeds, originating from New Guinea and possibly from the Moluccas and the Philippines. There is archaeological evidence of arboriculture in the Bismarck Archipelago before the Lapita Cultural Complex emerged c. 3400 years ago (Gosden 1992). Due to the lack of woody seeds or hard skin, breadfruit archeological remains have yet been found in Western Oceania, but it is most likely that domestication of breadfruit occurred in New Guinea and the Bismarck Archipelago through the selection of fruits with fewer seeds and more flesh (Lebot 1999). From c. 3200 BP, Lapita seafarers and their descendants migrated eastward into Remote Oceania (Santa Cruz Islands and beyond) carrying a number of staple crops in the form of seeds or root cuttings (Kirch 1997:203-212). The shift from sexual to vegetative propagation probably played a major 


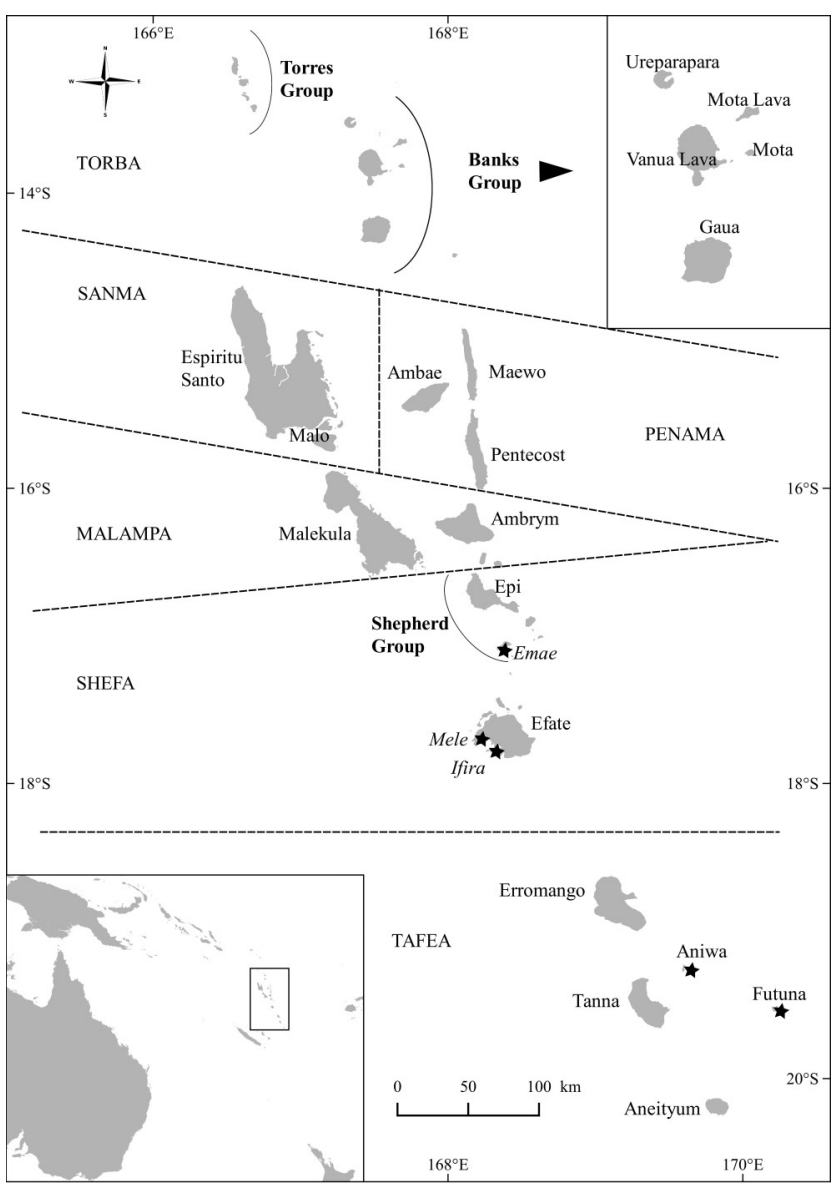

Figure 1 Map of Vanuatu with the provinces (in upper case), the groups of islands (in bold), and the main islands mentioned in the article (normal font). The stars show the Polynesian outliers (in italics).

role in breadfruit domestication by favoring the emergence of seedless triploid cultivars of $A$. altilis, which were preferentially propagated and dispersed in Eastern Polynesia (Ragone 2001). In contrast, a very large proportion of cultivars in Vanuatu and other countries of Western Oceania are seeded and presumably diploid, and show greater genetic diversity compared to the cultivars of Eastern Polynesia (Zerega et al. 2015).

\section{Vanuatu, a Pacific Crossroads and Center of Diversity}

The Republic of Vanuatu is an archipelago made up of 82 islands and islets straddling the $13^{\text {th }}$ and $22^{\text {nd }}$ parallels in the south-western Pacific Ocean (Figure 1), with evidence of settlement as early as $3000 \mathrm{cal}$ yrs BP (Petchey et al. 2014). Vanuatu may have acted as a crossroads among other archipelagoes (Solomons,
Fiji, and New Caledonia) during the Lapita expansion period and through the succeeding millennia (Bedford and Spriggs 2008). Polynesian contact is also attested with the settlement after the year AD 1000 of a few islands and islets by people originating from Western Polynesia (Shutler and Shutler 1966). As a consequence of its history, Vanuatu stands out through its great and still vigorous cultural diversity. Vanuatu is also a center of diversity for a large number of plants, such as tubers and root crops, bananas, kava (Piper methysticum), and fruit and nut trees (Lebot 1999). Great yam (Dioscorea alata) and taro (Colocasia esculenta) are the chief crops as, in addition to their status as main staple food, they are essential for holding customary ceremonies. Although less prestigious than root crops, fruit and nut trees are important components of subsistence agriculture, with a dozen cultivated species (Lebot et al. 2008). The last national agriculture census showed that breadfruit comes after cutnut (Barringtonia edulis) and Tahitian chestnut (Inocarpus fagifer) with 218,957 trees planted across the country, which amounts to approximately six breadfruit trees per rural household (VNSO 2008:116). However, that number varies considerably depending on the province. In Torba Province (Banks and Torres Groups), breadfruit ranks first among cultivated trees with an average of 17 trees per household, while in the southern Tafea Province, there are only 4.5 trees per household.

Going beyond the statistics and assessing the past and current importance and diversity of breadfruit on the islands of Vanuatu, more attention needs to be paid to ethnobotanical information, such as tree management practices, variety naming, food and nonfood uses, conservation techniques, cultural significance, as well as ritual magic intended to increase yields and protect the crop.

\section{First Historical Records}

The earliest description of breadfruit in Vanuatu was made in 1606 by Quirós on the island of Gaua in the Banks Group (Kelly 1966:201) and at Big Bay on the northern side of Espiritu Santo (Zaragoza 1876:338). In May 1768, Bougainville crossed the archipelago and landed on Ambae where the people brought him breadfruit and let him cut down breadfruit trees (La Roncière 1921:242; Taillemite 2006:254). In 1774, during the second voyage of James Cook, breadfruit was mentioned by the naturalist J. R. Forster in Port Sandwich, south east Malekula (Hoare 1982:568), and on Tanna (Hoare 1982:620). 
In 1839, the London Missionary Society established the first mission in the southern islands. Among the missionaries, Inglis (1890:114-116) made an accurate description of breadfruit production and uses on Aneityum, and Gunn (1914:181), who was a medical missionary from 1883 onward, did the same on Futuna. Further north, Murray (1894:36) listed the names of 65 varieties in the village of Ranon on Ambrym and Codrington (1891:304) counted 60 varieties of breadfruit on Mota, a small island of the Banks Group.

\section{Recent Surveys and Collections}

Brief mentions of breadfruit in Vanuatu can be found in publications by linguists, geographers, anthropologists, and agricultural specialists during the twentieth century, but the most detailed studies were conducted by Parham (1966) and, above all, by Walter in the 1980s (Walter 1989). Walter (1989) gives detailed ethnobotanical information (uses, management practices, legends), as well as a list of cultivar names and short descriptions of 130 cultivars recorded on eight islands.

More recently two surveys were conducted by Navarro, Labouisse, and Malres in 2004-2005, and by Mies and Malapa in 2009, both in partnership with the Vanuatu Agricultural Research and Technical Center (VARTC) and with the support from the Pacific Plant Genetic Resources Network (PAPGREN). Results of the first survey were reported in a short communication during the first international symposium on breadfruit held in Fiji in 2007 (Navarro et al. 2007). By merging the data from both survey campaigns, Mies (2009) compiled a catalogue of 222 accessions observed in 31 villages. This unpublished catalogue presents passport data (location, cultivar name), morphological data, cooking methods, miscellaneous uses, and provides pictures of the main parts of the trees. When possible, suckers were taken from roots and, after transfer to VARTC, a hundred cultivars were established in a field genebank where they are being characterized following standard descriptors.

\section{Breadfruit Tree Management Practices}

In Vanuatu, the breadfruit tree is found in several landscape settings: backyards, along roads and paths, borders of gardens, coconut and cocoa plantations, but also in abandoned inland villages and gardens, as well as in forest areas on the larger islands. The seeded forms largely predominate in the country but both ways of propagation (from seeds and from root suckers) coexist (Walter 1989). It is likely that a significant proportion of trees are deliberately planted after clonal propagation of forms selected by people according to various criteria (yield, seasonality, fruit size and shape, flesh color and taste, number of seeds, and use). In forest areas and plantations, trees are often born from seeds dispersed by animals, such as flying foxes of the genus Pteropus (Banack 1998). These feral trees constitute a large reservoir of diversity that exhibits recombined characters of parental trees. If one of them shows outstanding or uncommon characters, it may be propagated by root suckers and planted in other places. Typically, it is given a cultivar name at that stage. This selection process was described to us by the chief Tari Vira of Malo during our 2004 survey (Navarro et al. 2007).

\section{Breadfruit Cultivars}

Vanuatu is one of the most diverse nations in terms of the number of indigenous languages per head of population. Tryon (1997) quoted a figure of 113 languages, some of them spoken by a handful of people. Because of the biology of breadfruit, which is heterozygous and sometimes propagated by seeds, and the number of languages spoken in Vanuatu, a very large number of cultivar names might be expected at island and country levels. Indeed, a database of 580 named entries has been compiled from various sources (Supplementary Table 1). Once synonyms and very similar names were discarded, 539 distinct names were left. The local taxonomy for the cultivars follows the model described by Ragone et al. (2004) with a binomial composed of a local head term for breadfruit modified by a descriptive term, or with a monomial in which a descriptive term is used and the term for breadfruit is understood.

\section{Breadfruit as a Food}

The simplest way to prepare breadfruit is to roast it whole on coals or directly in the fire. This process is used for ordinary home meals, but also when taking a break from gardening or fishing. The fruit can be boiled or baked in an earth oven, wrapped in Heliconia leaves, either cut into large chunks or grated to make a laplap $[\mathrm{bis}]^{1}$ pudding.

Nalot [bis] is the most popular dish made with breadfruit throughout Vanuatu. In the past nalot was exclusively prepared by men and consumed during ceremonies and festivals. Now it is prepared on feast days, during a family event, or to honor a foreign visitor. The fresh fruit is roasted in the fire, then the 


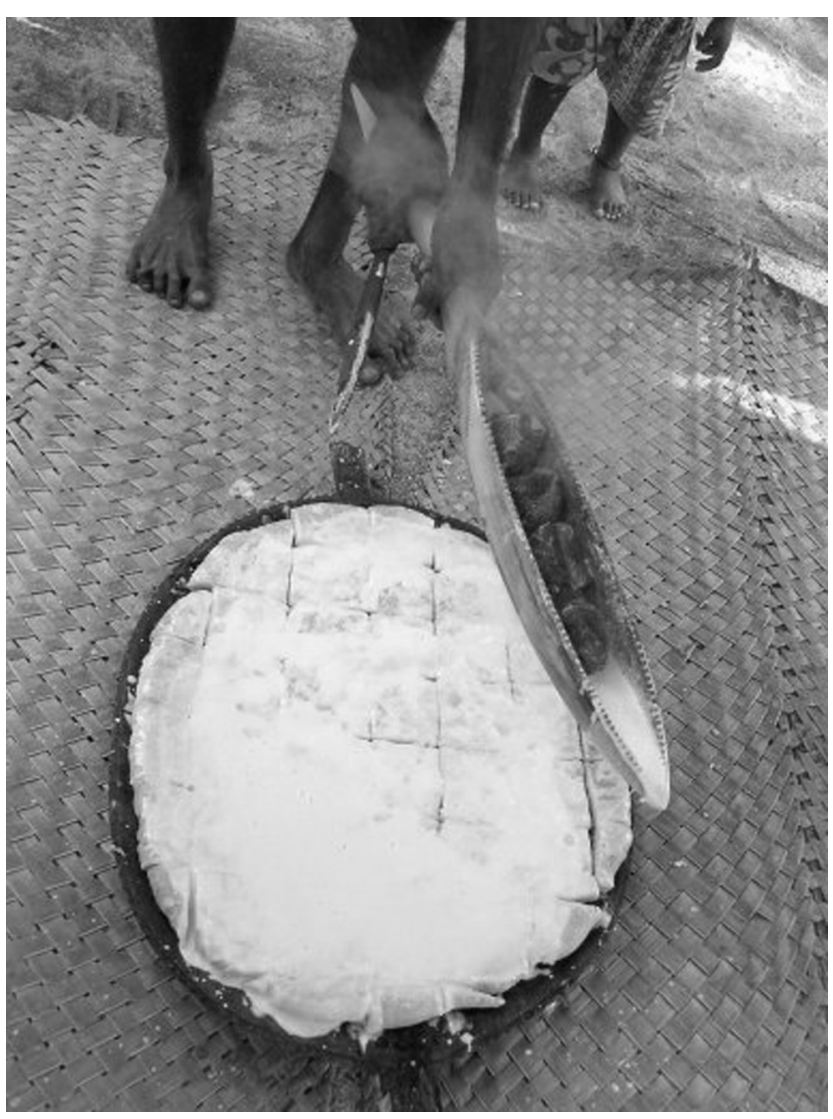

Figure 2 Nalot of breadfruit (Ureparapara, Banks Group). The large wooden spoon contains hot stones to heat the coconut milk that is poured on the paste. Note the wooden knife in the right hand of the person. Photo by Christophe Jourdan, 2002.

rind, the core, and the seeds are removed. The flesh is placed on a wooden plate and pounded with a pestle. Coconut milk is added and the mass thoroughly mixed. Then the pudding is laid on a wooden dish, gently hollowed with the skin of a coconut, and filled with hot coconut milk (Figure 2). In the north of Vanuatu fine wooden artifacts (platters, spoons, pounders, and long knives) were found to be associated with the preparation and eating of nalot (Huffman 1996a, b, c; Rivers 1914:81-82).

\section{Conservation techniques}

Local conservation techniques were developed to deal with the seasonal nature of production and the risk of food shortages of staple crops, which result from cyclones, drought, or even earthquakes that can damage taro pond-field systems (Walter 1989).

The conservation of breadfruit by fermentation in an earth pit developed widely in Micronesia and
Polynesia where it is known under the names mar (Ponape, Yap), ma (Marquesas Islands), mahi (Society Islands), or masi (Samoa). Storage under quasianaerobic conditions induces a decrease in $\mathrm{pH}$ through the conversion of starchy components into lactic acid, which further inhibits degradation by microorganisms. The paste thus remains edible in the pits for many years. Regional variations in the methods of preparation have been extensively described for other Pacific countries (Atchley and Cox 1985; Cox 1980; Pollock 1992; Ragone 1991, 2002; Yen 1974). In Vanuatu, breadfruit fermentation seems to have once been widespread in the central and southern islands, the Polynesian outliers Futuna and Aniwa, as well as on Malo. On Aneityum, archaeological excavations by Shulter and Shulter (1966) attest to the existence of numerous earth pits dating to the preEuropean period. Pit fermentation techniques were described by Inglis (1890:115-116) for this island, where we saw a small pit (namarai) during our survey in the village of Anelgowhat in 2004 (Navarro et al. 2007). The fermented paste is called namarai-ma, inma being the generic term for breadfruit in Aneityumese. On Erromango, it is called namandaï (Barrau 1957). On Futuna, mara refers to both the fermented paste and the pit (Dougherty 1983:358). On Epi, Walter (1989) reported the preparation of earth pits called mele, which, in the past, were distributed in several places inland where men used to spend time clearing forest and gardening. On Tongoa, the preparation of pits called navinang was reported by Weightmann (1989:114). Preparation may sometimes include a phase of soaking in the sea as described in the area of Melsisi on Pentecost by Barrau (1957) and Walter (1989). The fruit is cut into pieces, placed in holes in the coral reef and covered with leaves and stones. After alternate phases of salt water soaking and sun exposure, the fermented pulp is pounded, mixed with coconut milk and cooked inside small bamboo sticks. Less common and probably less valued in the past than in Polynesia and Micronesia, where fermented food prepared in large quantities played an important role in the prestige economy, the practice of fermenting breadfruit, with some exceptions, seems nevertheless to have almost completely disappeared from Vanuatu. The risk of food shortages has been reduced by the introduction of crops, such as cassava, sweet potato, and cocoyam (Xanthosoma sagittifolium), which are less seasonal than breadfruit and can be better preserved. Moreover, the introduction of a cash economy substantially increased the consumption of 


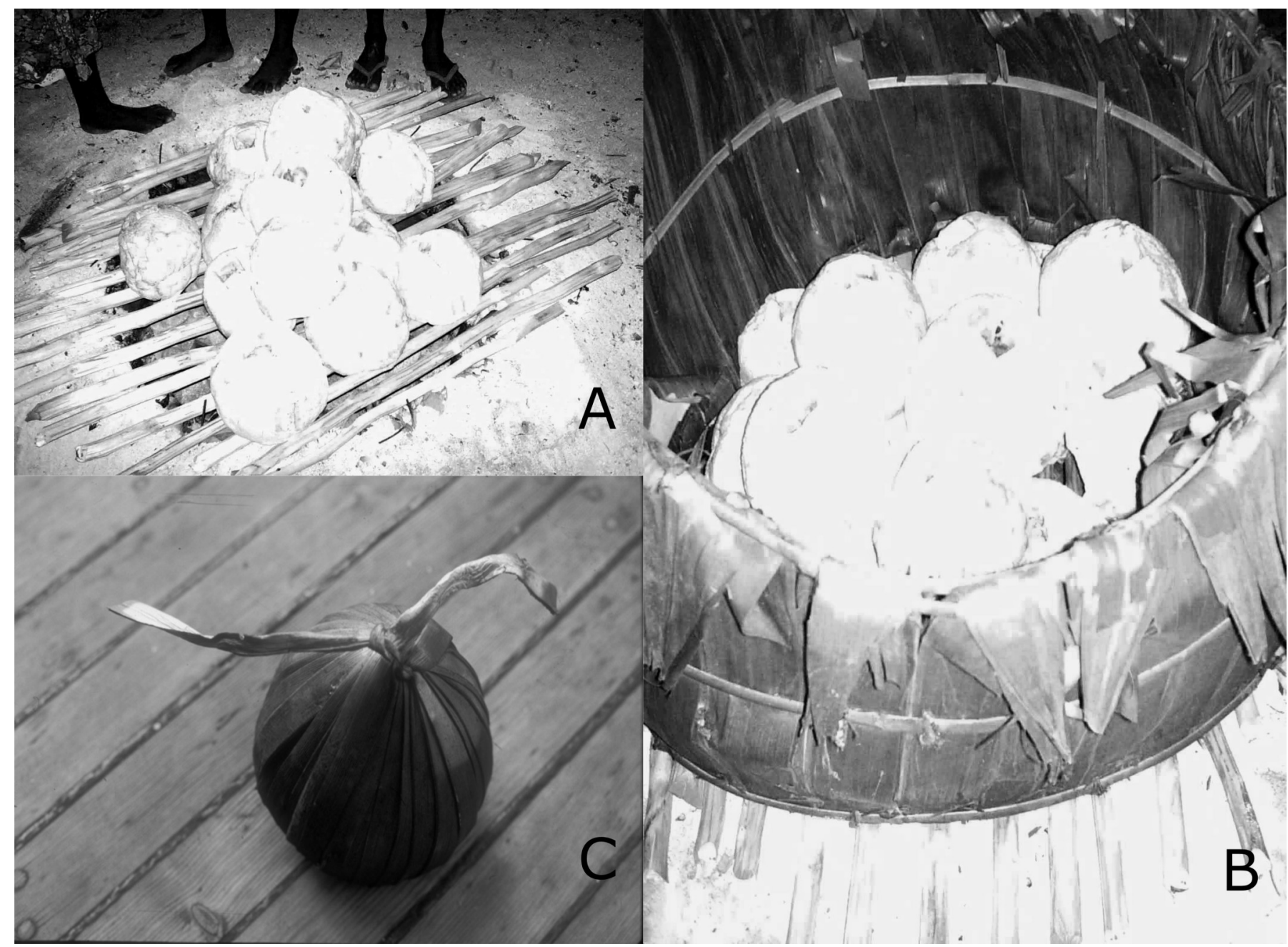

Figure 3 Preparation of dried breadfruit nekey (Mota Lava). A Peeled fruit is placed on wooden sticks over hot stones. B The oven is surrounded by a framework of flexible wood lined with pandanus leaves. Other leaves will be placed on the top. C The dried fruit is tied with pandanus ribbons. Photos by Muriel Navarro, 2004.

imported rice, which is always available for purchase in rural stores or can be rapidly shipped in the event of a natural disaster.

In the Banks Group, dried breadfruit (or bredfrut bisket [bis]) is obtained by drying the whole fruit in an oven (netetve) made for that purpose (Figure 3). Dried breadfruit is called nekey on Mota Lava and kor in Mota. The nekey can be kept for years. It is used as a non-perishable, easy-to-transport food-typically by fishermen at sea-but it can also be given as a gift or be part of exchanges during customary ceremonies. It is generally consumed after pieces are dipped into tea or infusions of orange leaves (S. Caillon, personal communication). This preparation of dried breadfruit seems to have been confined to the northern islands and more specifically to Mota Lava and Mota—the latter is called Ure kor in Mota language, which means "the place full of dried breadfruit" (Codrington 1891:7).

\section{Leaves}

Breadfruit leaves are sometimes used for wrapping food before cooking it in an earth oven or on fire coals. Young leaves may be cooked over a fire inside bamboo sticks (Walter 1989) and/or added to laplap pudding like for other leafy vegetables (Navarro et al. 2007).

\section{Breadfruit Tree Wood}

Canoe Making

First mentioned by Bougainville in Tahiti, one of the most attested non-food uses of the breadfruit tree is 
for canoe making (e.g., Henry 1928:549; Ragone 1991). In Vanuatu such use was reported by Inglis (1890:114) on Aneityum where the breadfruit tree is preferred to all others for that purpose. Similar reports exist for Malekula (Deacon 1934:206-207), Futuna (Capell 1958:25), Mota Lava (Vienne 1984:129), and Tanna (Iati 2012:41).

\section{Slit Gongs}

Music plays an essential role in ceremonies organized for transitional life events, such as initiation, gradetaking, and death. Customary dances are accompanied by several instruments, the most common one being a large wooden gong that is hollowed out from a tree trunk, slit lengthwise, and often embellished at the top with a stylized face. Their confection from breadfruit wood was reported by Deacon (1934:507) on Malekula, Guiart (1956a) on Ambrym, and Ammann (2012:137, 154) in the Banks Group.

\section{Other Uses}

Mixed with coconut fiber, breadfruit sap is used for canoe caulking (Deacon 1934:206). Breadfruit sap is also used to glue feathers on masks (Navarro et al. 2007) or, mixed with sawdust or clay to form a sticky paste, to coat sculptures made from wood or fern trunks (Deacon 1934:398, 545; Guiart 1951). Birds and small predators are still trapped using breadfruit latex (Walter 1989). In the traditional pharmacopeia of Vanua Lava, breadfruit sap is used to treat menorrhagia (Bourdy and Walter 1992). On Aneityum, it is applied to wounds (Bradacs 2008:75). Breadfruit tree shoots mixed with Macaranga dioica (navenu) are used to treat headaches and migraines (Bradacs et al. 2011).

\section{Ritual Magic}

Like most traditional activities, gardening required magical practices to control climate, soil fertility, and to increase and protect crop production. This occurred through seasonal rites performed by garden magicians (Firth 1930). In Vanuatu, although yam and taro are the crops most often implicated in these activities, such practices still occur on several islands through the use of sacred stones. On Futuna, Gunn (1914:221) reported that "the stones for causing bread -fruit to grow were almost exactly like the fruit." On Mota-Lava and on Malo, the stones were buried near the base of breadfruit trees or placed at the junction of branches (Codrington 1891:183; Vienne 1984:112; Walter et al. 1999:54). On Malekula, the stones were kept in clay pots (Deacon 1934:612) and on Tanna in wooden canoes conserved inland, in sacred places that are reserved for magicians (Bonnemaison 1991; Guiart 1956b:37-40; Iati 2012:81-82).

\section{Myths and Legends}

Myths, legends and other stories related to breadfruit are numerous in Polynesia (Meilleur et al. 2004:13-15; Ragone 1991), but few have been collected in Vanuatu. Two stories reported by Walter (1989) are summarized here. In Marpagho, southern Malekula, it is said that the first breadfruit was born from the breast of a woman who cut it off herself to feed her small sister, in all likelihood an analogy between latex and milk as a source of food. In central Pentecost, ten brothers tried to propagate a tree by planting different parts of it (flower, leaf, bark, etc.) but only one, a man named Birisilsil, succeeded by sowing seeds. From that time, people of Pentecost preferred to propagate breadfruit from seeds rather than from root suckers.

\section{Conclusion and Prospects}

By combining historical and ethnobotanical data from a variety of sources, our knowledge and understanding of the importance and status of breadfruit in the islands of Vanuatu are increasing. Breadfruit is present everywhere in the archipelago, but it appears particularly important on the smaller islands of the Banks and the Shepherd Groups, on Futuna and on Malo where land resources are limited, but also on Ambrym where crop cultivation is often affected by drought and occasional volcanic ash fall. It is not surprising then that different preservation techniques were developed on these islands. While recent statistics for Tafea province show a small average number of trees per household, two islands of that province, Tanna and Aneityum, can also be described as "islands of breadfruit," characterized by complex abundanceenhancing rituals and the use of pit preservation.

More in-depth studies on the cultural and social aspects are required to better understand how the planting material (seeds or cuttings) circulate among landscape features, among people, and among islands. There is a lack of detailed studies about many aspects of current management practices (selection criteria, proportion of trees obtained by each method of propagation), which appear to vary from island to island. Additional surveys should be carried out to expand country coverage. Morphological and ethnobotanical descriptions of cultivars should be supplemented with genetic characterizations. For example, one genotype may have multiple names in different languages, and distinct genotypes may share the same 
cultivar name. Recent advances in molecular marker techniques for breadfruit (Gardner et al. 2015; Witherup et al. 2013) provide valuable tools for characterizing the uniqueness of a genotype, tracing its origin and perhaps also indicating its propagation history.

Bonnemaison (1974) has described the impact of copra industry development and that of other cash crops (cocoa and coffee) on the process of "disintensification" of Vanuatu agriculture. Changes in the traditional food economy have already resulted in a degree of crop diversity erosion (number of cultivated varieties) and in knowledge related to cultivation, uses, and processing methods. These are coupled with an increasing dependency on imported foods and dietary changes now contributing to a high prevalence of obesity and related health problems. Nevertheless, information gathered during the most recent surveys seems to show that local knowledge of breadfruit is still vigorous in many areas of Vanuatu. A significant number of named cultivars and their distinctive characteristics are still known, probably because many trees are planted in backyards, facilitating intergenerational knowledge transfer. In most rural areas, breadfruit is secondary to root crops and rice in the daily diet, but nalot is still valued and, while pit conservation has almost completely disappeared, nekey-making has withstood the imported foods and remains a source of pride in Mota Lava. In the agroclimatic conditions of Vanuatu, breadfruit trees once established require low energy and other inputs. As a starchy crop, it is the only tree crop that provides "real food" (Pollock 1992:22) as well as non-food products and services. Genetic diversity is maintained thanks to the use of both seeds and root cuttings. All these characteristics may make rural households more resilient to natural disasters and economic shocks, as occurs when prices drop for cash crops (Lebot and Siméoni 2015). Breadfruit diversity, management practices, and uses deserve to be better documented and promoted in Vanuatu to allow for adaptation to environmental and economic change, as well as for food security and sustained human health.

\section{Notes}

${ }^{1}$ bis $]=$ Bislama term. Bislama is the Vanuatu variety of Pacific English-based pidgins.

\section{Acknowledgements}

The author thanks Peter Biggins and Brien Meilleur for editorial input.

\section{Declarations}

Permissions: Permission was obtained from Christophe Jourdan and Muriel Navarro to use their photographs.

Sources of Funding: None declared.

Conflicts of Interest: None declared.

\section{References Cited}

Ammann, R. 2012. Sounds of Secrets: Field Notes on Ritual Music and Musical Instruments on the Islands of Vanuatu. LIT Verlag, Zurich, Switzerland.

Atchley, J., and P. A. Cox. 1985. Breadfruit Fermentation in Micronesia. Economic Botany 39:326-335. DOI:10.1007/BF02858803.

Banack, S. A. 1998. Diet Selection and Resources Used by Flying Foxes (Genus Pteropus). Ecology 76:1949-1967. DOI:10.1890/0012-9658(1998)079 [1949:dsarub]2.0.co;2.

Barrau, J. 1957. L'Arbre à Pain en Océanie. Journal d'Agriculture Tropicale et de Botanique Appliquée 4:117-123.

Barrau, J. 1958. Subsistence Agriculture in Melanesia. Bernice P. Bishop Museum, Honolulu, HI.

Bedford, S., and M. Spriggs. 2008. Northern Vanuatu as a Pacific Crossroads: The Archaeology of Discovery Interaction and the Emergence of the Ethnographic Present. Asian Perspectives 47:95120. Available at: http://

hdl.handle.net/10125/17282. Accessed on January 4, 2016.

Bonnemaison, J. 1974. Espaces et Paysages Agraires dans le Nord des Nouvelles-Hébrides. Journal de la Société des Océanistes. 30:163-232. DOI:10.3406/ jso.1974.2676.

Bonnemaison, J. 1991. Magic Gardens in Tanna. Pacific Studies 14:71-89.

Bourdy, G., and A. Walter. 1992. Maternity and Medicinal Plants in Vanuatu. Journal of Ethnopharmacology 37:179-196. DOI:10.1016/0378-8741(92) 90033-N.

Bradacs, G. 2008. Ethnobotanical Survey and Biological Screening of Medicinal Plants from Vanuatu. Doctoral Dissertation. University of Regensburg, Regensburg, Germany.

Bradacs, G., J. Heilmann, and C. Weckerle. 2011. Medicinal Plant Use in Vanuatu: A Comparative Ethnobotanical Study of Three Islands. Journal of 
Ethnopharmacology 137:434-448. DOI:10.1016/ j.jep.2011.05.050.

Capell, A. 1958. The Culture and Language of Futuna and Aniwa, New Hebrides. Oceania Linguistic Monographs No. 5. University of Sydney, Sydney, Australia.

Codrington, R. H. 1891. The Melanesians. Studies in their Anthropology and Folk-lore. Clarendon Press, Oxford.

Cox, P. A. 1980. Two Samoan Technologies for Breadfruit and Banana Preservation. Economic Botany 32:181-185. DOI:10.1007/BF02858634.

Deacon, A. B. 1934. Malekula: A Vanishing People in the New Hebrides. George Routledge \& Sons, London.

Dougherty, J. W. D. 1983. West Futuna-Aniwa: An Introduction to a Polynesian Outlier Language. Linguistics Volume 102. University of California Press. Berkeley, CA.

Firth, R. 1930. Totemism in Polynesia. Oceania 1:291 -321 .

Gardner, E. M., K. M. Laricchia, M. Murphy, D. Ragone, B. E. Scheffler, S. Simpson, E. W. Williams, and N. J. C. Zerega. 2015. Chloroplast Microsatellite Markers for Artocarpus (Moraceae) Developed from Transcriptome Sequences. Applications in Plant Sciences 3:9. DOI:10.3732/ apps.1500049.

Gosden, C. 1992. Production Systems and the Colonization of the Western Pacific. World Archaeology 24:55-69.

DOI:10.1080/00438243.1992.9980193.

Guiart, J. 1951. Sociétés, Rituels et Mythes du Nord Ambrym. Journal de la Société des Océanistes 7:5103. DOI:10.3406/jso.1951.1692.

Guiart, J. 1956a. Notes sur les Tambours d'Ambrym. Journal de la Société des Océanistes 12:334-336.

Guiart, J. 1956b. Un Siècle et Demi de Contacts Culturels à Tanna, Nouvelles-Hébrides. Publications de la Société des Océanistes No 5, Musée de l'Homme, Paris.

Gunn, W. 1914. The Gospel in Futuna. Hodder and Stoughton, London.
Henry, T. 1928. Ancient Tahiti. Bernice P. Bishop Museum Bulletin 48. Bishop Museum Press, Honolulu, HI.

Hoare, M. E. 1982. The Resolution Journal of Johann Reinhold Forster 1772-1775. Vol 4. The Hakluyt Society, London.

Huffman, K. 1996a. Wooden Nalot Pounders. In Arts of Vanuatu, edited by J. Bonnemaison, K. Huffman, C. Kaufmann, and D. Tryon, pp. 104-107. University of Hawai'i Press, Honolulu, HI.

Huffman, K. 1996b. Plates and Bowls from Northern and Central Vanuatu. In Arts of Vanuatu, edited by J. Bonnemaison, K. Huffman, C. Kaufmann, and D. Tryon, pp. 226-231. University of Hawai'i Press, Honolulu, HI.

Huffman, K. 1996c. Wooden and Bamboo Food Knifes from Northern Vanuatu. In Arts of Vanuatu, edited by J. Bonnemaison, K. Huffman, C. Kaufmann, and D. Tryon, pp. 232-233. University of Hawai'i Press, Honolulu, HI.

Iati, B. 2012. Les Pirogues à Balancier des Iles du Sud du Vanuatu. Master's Thesis. Vanuatu Kaljoral Senta, Port-Vila, Vanuatu. Available at: http:// vanuatuculturalcentre.vu/wp-content/ uploads/2013/02/Bergmans-Iati.-Les-pirogues- $\%$ C3\%A0-balancier-au-sud-du-Vanuatu.pdf. Accessed on January 4, 2016.

Inglis, J. 1890. Bible Illustration from the New Hebrides. Thomas Nelson, London.

Kelly, C., ed. 1966. La Austrialia del Espíritu Santo. Hakluyt Society. Cambridge University Press, Cambridge, MA.

Kirch, P. V. 1997. The Lapita Peoples: Ancestors of the Oceanic World. Wiley-Blackwell, Cambridge, MA.

La Roncière (de), C. 1921. Le Routier Inédit d'un Compagnon de Bougainville, Louis Antoine de Saint Germain (1767-1768). La Géographie 35:217-250.

Lebot, V. 1999. Biomolecular Evidence for Plant Domestication in Sahul. Genetic Resources and Crop Evolution 46:619-628. DOI:10.1023/ A:1008748504038.

Lebot, V., P. Siméoni. 2015. Community Food Security: Resilience and Vulnerability in Vanuatu. Human Ecology 43:827-842. DOI:10.1007/s10745015-9796-3U. 
Lebot, V., A. Walter, and C. Sam. 2008. Domestication of Indigenous Fruit and Nut Tree Species in Vanuatu, Oceania. In Indigenous Fruit Trees in the Tropics, edited by F. K. Akinnifesi, R. R. B. Leakey, O. C. Ajayi, G. Sileshi, Z. Tchoundjeu, P. Matakala, and F. R. Kwesiga, pp. 120-136. CABI. Wallingford, UK. DOI:10.1079/9781845931100.0120.

Lepofsky, D. 2003. The Ethnobotany of Cultivated Plants in the Maohi of the Society Islands. Economic Botany 57:73-92. DOI:10.1663/0013-0001(2003) 057[0073:teocpo]2.0.co;2.

Meilleur, B. A., R. R. Jones, C. A. Titchenal, and A. S. Huang. 2004. Hawaiian Breadfruit: Ethnobotany, Nutrition, and Human Ecology. College of Tropical Agriculture and Human Resources, Honolulu, HI.

Mies, A. 2009. The Vanuatu Breadfruit Project, February-August 2009, Final Report. VARTC, SPC \& CIRAD. Unpublished Document.

Murray, C. 1894. Varieties of Breadfruit, New Hebrides. Journal of Polynesian Society 3:36.

Navarro, M., S. Malres, J. P. Labouisse, and O. Roupsard. 2007. Vanuatu Breadfruit Project: Survey on Botanical Diversity and Traditional Uses of Artocarpus altilis. In Proceedings of the 1st International Symposium on Breadfruit Research and Development, Nadi, Fiji, April 16-19, 2007, edited by M. B. Taylor, J. Woodend, and D. Ragone, pp. 81-87. Acta Horticulturae, 757. IHSH, Louvain, Belgium. DOI:10.17660/ActaHortic.2007.757.9.

Parham, J. W. 1966. Coconut and Breadfruit Survey in the South Pacific Region. South Pacific Commission, Noumea, New Caledonia.

Petchey, F., M. Spriggs, S. Bedford, F. Valentin, and H. Buckley. 2014. Radiocarbon Dating of Burials from the Teouma Lapita Cemetery, Efate, Vanuatu. Journal of Archaeological Science 50:227-242. DOI:10.1016/j.jas.2014.07.002.

Pollock, N. 1992. These Roots Remain: Food Habits in Islands of the Central and Eastern Pacific since Western Contact. The Institute of Polynesian Studies. Laie, HI.

Ragone, D. 1991. Ethnobotany of Breadfruit in Polynesia. In Islands, Plants and Polynesians: an Introduction to Polynesian Ethnobotany, edited by P. A. Cox and S. A. Banack, pp. 203-220. Dioscorides Press. Portland, OR.
Ragone, D. 1997. Breadfruit: Artocarpus altilis (Parkinson) Fosberg. IPGRI, Rome.

Ragone, D. 2001. Chromosome Numbers and Pollen Stainability of Three Species of Pacific Island Breadfruit (Artocarpus, Moraceae). American Journal of Botany 88:693-696. Available at: http:/ / www.amjbot.org/content/88/4/693.long. Accessed on January 4, 2016.

Ragone, D. 2002. Breadfruit Storage and Preparation in the Pacific. In Vegeculture in Eastern Asia and Oceania. JCAS Symposium Series 16, edited by S. Yoshida, Y. Ochai, and P. J. Matthews, pp. 217-32. The Japan Center for Area Studies. National Museum of Ethnology, Osaka, Japan.

Ragone, D., G. Tavana, J. M. Stevens, P. A. Steward, R. Stone, P. M. Cox, and P. A. Cox. 2004. Nomenclature of Breadfruit Cultivars in Samoa: Saliency, Ambiguity, and Monomiality. Journal of Ethnobiology 24:33-49.

Rivers, W. 1914. The History of Melanesian Society. Vol. 1. Cambridge University Press, Cambridge, MA.

Shutler, M., and R. Shutler. 1966. A Preliminary Report of Archaeological Explorations in the Southern New Hebrides. Asian Perspectives 9:157166.

Taillemite, E. 2006. Bougainville et ses Compagnons autour du Monde 1766-1769. Imprimerie Nationale, Paris.

Tryon, D. T. 1997. Dialect Chaining and the Use of Geographical Space. In Arts of Vanuatu, edited by J. Bonnemaison, K. Huffman, C. Kaufmann, and D. Tryon, pp. 172-183. Crawford House, Bathurst, Australia.

Vienne, B. 1984. Gens de Motlav. Idéologie et Pratique Sociale en Mélanésie. Société des Océanistes, Paris.

VNSO. 2008. Vanuatu Census of Agriculture 2007. Vanuatu National Statistics Office. Port Vila, Vanuatu.

Walter, A. 1989. Notes sur les Cultivars d'Arbre à Pain dans le Nord du Vanuatu. Journal de la Société des Océanistes 88-89:3-18. DOI:10.3406/ jso.1989.2850.

Walter, A., D. Greindl, F. Tzerikiantz, and M. Allen. 1999. Transformation de la Sphère Alimentaire au 
Vanuatu : des Moyens Nouveaux pour des Objectifs Identiques. Journal d'Agriculture Tropicale et de Botanique Appliquée 41:33-59.

Weightman, B. 1989. Agriculture in Vanuatu. A Historical Review. The British Friends of Vanuatu, Cheam, UK.

Witherup, C., D. Ragone, T. Wiesner-Hanks, B. Irish, B. Scheffler, S. Simpson, F. Zee, M. I. Zuberi, and N. J. C. Zerega. 2013. Development of Microsatellite Loci in Artocarpus altilis (Moraceae) and Crossamplification in Congeneric Species. Applications in Plant Sciences 1:apps.1200423. DOI:10.3732/ apps.1200423.

Yen, D. E. 1974. Arboriculture in the Subsistence of Santa Cruz, Solomon Islands. Economic Botany 28:247-284. DOI:10.1007/BF02861424.

Zaragoza, J., ed. 1876. Historia del Descubrimiento de las Regiones Austriales Hecho por el General Pedro
Fernandez de Quirós. Vol. 1. M. G. Hernandez, Madrid.

Zerega, N. J. C., D. Ragone, and T. J. Motley. 2004. Complex Origins of Breadfruit (Artocarpus altilis, Moraceae): Implications for Human Migrations in Oceania. American Journal of Botany 91:760-766. DOI:10.3732/ajb.91.5.760.

Zerega, N. J. C., T. Wiesner-Hanks, D. Ragone, B. Irish, B. Scheffler, S. Simpson, and F. Zee. 2015. Diversity in the Breadfruit Complex (Artocarpus, Moraceae): Genetic Characterization of Critical Germplasm. Tree Genetics \& Genomes 11:1-26. DOI:10.1007/s11295-014-0824-z.

Supplementary File is linked to the online version of the paper at ojs.ethnobiology.org/index.php/ebl. 